\title{
Financial Crisis and Its Impact on the Economies of China and India
}

\author{
Kalim Siddiqui \\ Department of Strategy and Marketing \\ The Business School, University of Huddersfield \\ Queesngate, Huddersfield - HD 1 3DH, United Kingdom \\ Tel: + 44 (0) 1484 - 473615; Fax: + 44 (0) 1484 - 473148 \\ E-mail:k.u.siddiqui@hud.ac.uk
}

\begin{abstract}
The study will focus on the current financial crisis and its impact on the growth, trade and employment in emerging market economies (EMEs) namely China and India. The emerging market economies are characterized as transitional, which means that they are in the process of moving from a closed to an open market economy. It is said that by adoption of neoliberal policies, the economy will suppose to lead to a better economic performance levels, as well as transparency and efficiency in the capital market.

The proponents of the 'neoliberal economic policies' always maintained that it is working and as a consequence, for example, the Indian economy is growing at high rates, the stock market is booming, foreign reserve is at a comfortably high level. The 'free trade' policy is making availability of a variety of goods unimaginable earlier as a mark of the benefits of globalization. The 'invisible hand' of the market, tries to pretend that market operates in isolation. On the basis most recent available data and studies the author has examined the impact of financial crisis on the economic growth and various sectors of the economies in China and India.

Finally, the author finds the argument that China emerging as the alterative engine of growth for the world economy is too ambitious. Some have suggested that a 'decoupled Asia' through its own growth and expanding domestic demands would ensure higher imports demands for its growing economies and thus limit the economic slowdown in the developed economies. But this is unlikely due to: the US, EU and Japan together account for more than half of China's exports, and as recession deepens, it is bound to affect export sector and overall economic activity in China.
\end{abstract}

Keywords: Financial crisis, emerging market economies, India, China, neo-liberalism, FDI, growth rates and economic crisis. 


\section{Introduction}

The financial crisis began in August 2007 in the US and West European countries and it has since affected the developing countries. This article attempts to examine the impact of current global financial crisis on the emerging economies namely China and India. I think a critical analysis is important on this issue because these two countries together constitute more than one-third of the world's population. Moreover, since the adoption of neoliberal economic reforms (also known as 'market-friendly' policies) both economies had experienced rapid economic growth and thus projected by the International Monetary Fund (IMF) and World Bank as successful examples towards removal of unemployment and poverty (Winters and Yusef 2007; Dyer 2009a; Bradsher 2009a).

When the financial crisis started in the US, the mainstream economists and international financial institutions claimed that it would have marginal or no impact on the emerging economies of namely China and India because of the 'decoupling' effects and also because these economies have adopted market reforms which had made these economies more efficient and competitive so that they could withstand such challenges (The Economist 2008a; Wolf 2008; Boothe 2008; Bradsher 2009b; Dyer 2009b). Here the purpose of this article is to study the external factors behind the recent slowdown in the economies of emerging markets.

The term "financial crisis" is broad term that covers a range of events such as crashes in the housing market, banking sectors and of course recession (Siddiqui 2008b). The world economic crisis first surfaced in the US sub-prime mortgage market in August 2007, soon spread to other areas both in US and other European countries. Within few months a huge financial meltdown was witnessed (i.e. bankruptcies of banks and insurance firms) in many developed countries (The Economist 2008b and also 2008c; Felton and Reinhart 2008).

The study will primarily focus on the current financial crisis and its impact on the growth, international trade and employment in emerging market economies (EMEs) namely China and India. More recently China and India for example, have witnessed a sharp decline in the demand for exports, foreign institutional investments and the real estate prices (Wade 2009; The Economist 2009a).

It is significant to understand the impact of current global crisis on Asian economies and emerging economies in particular because optimists pointed out earlier these economies would act as the shock absorber that would act as buffer to the Western economic slowdown. It was further suggested that a 'decoupled Asia' through its own growth and expanding domestic demands would ensure higher imports demands for its growing economies and thus limit the economic slowdown in the developed economies. From the onset of the financial crisis the optimists were of the view that the Asian countries had undertaken market-friendly i.e. neoliberal economic reforms and that had strengthened these economies to withstand such situations. Asian economies so-called "success story" were crucial for the justification of the neoliberal policies as it was said that adoption of these very policies had helped them to achieve higher growths. However, neoliberal economic policies were losing credibility in Latin America and African countries (Siddiqui 1990a \& also 1998; Williamson 1994; Patnaik 2009).

The economy in China and India has been rising in recent years but Chinese economy today 
is not big enough to pull the rest of the world economy. At current exchange rates the IMF calculates its GDP in 2006 as US\$ 2,600 bn - just behind Germany, while less than one-fifth of the size of US. However, GDP can also be measured in Purchasing Power Parity (PPP), which is based on domestic buying power. Meanwhile, China only accounts for $5 \%$ of global buying power and thus will not be able to compensate for the effect of a major economic crisis that accounts for over $20 \%$ (Wolf 2008; Soros 2009). In India despite rapid growth rates, still only $42.1 \%$ of the urban workforce were "regular employees", while $41.7 \%$ were categorized as "self-employed", and $16.2 \%$ as "casual employees" in 1993. There is no dramatic change has happened since then, as employment growth is only $1 \%$ annually and even less in the manufacturing sector (Dasgupta and Singh 2006).

More recently it has been increasingly acknowledged that financial crisis is adversely affecting the economies of the emerging markets. For example, The Economist notes, "China's breakneck growth has stalled. The rest of East Asia, too, which had hoped that it was somehow "decoupled" from the economic trauma of the West, has found itself hit as hard as anywhere in the world-and in some cases harder... The scale and speed of that downturn is breathtaking and broader in scope than in the financial crisis of 1997-98. China's GDP, which expanded by $13 \%$ in 2007, scarcely grew at all in the last quarter of 2008 on a seasonally adjusted basis. In the same quarter Japan's GDP is estimated to have fallen at an annualized rate of $10 \%$. Singapore's at $17 \%$ and South Korea's at $21 \%$ ” (The Economist 2009b:10). It was emphasized that the impact would be mainly through the trade channel. Both Chinese and Indian economies have high degree of "openness" as measured by trade and financial flows. In India for example, merchandise exports account for less than $15 \%$ of GDP, the trade channel impact was assumed to be bearable (The Economist, 2009a).

The proponents of the 'neoliberal economic policies' always maintained that it is working and as a consequence, for example, the Indian economy is growing at high rates, the stock market is booming, foreign reserve is at a comfortably high level (Siddiqui 2009a and 2009b). The 'free trade' policy is making availability of a variety of goods unimaginable earlier as a mark of the benefits of globalization. The 'invisible hand' of the market, tries to pretend that market operates in isolation. However, $19^{\text {th }}$ century capitalism in the west Europe was developed through a process of active state to develop market forces. Karl Polanyi (1944) termed this as a process of "great transformation" driven by the "double movement" of the market and the state, a process in which the rules of the market were broadly set by the state. Hence, state clearly stood for the interest of market but regulated it.

It is claimed that 'free market' policy and 'international openness' would increase economic growth and create jobs. I will argue that this argument is incorrect. Since 'globalization' tends to increase the relative importance of the external vs the internal market. The dependence on foreign market through export and foreign investments will increase (Siddiqui 2008c). Then the state will be more sensitive to the needs of foreign corporations. On economic front, this has to be achieved through greater international cost competitiveness by measures like wage restraint, tax concessions, privatization, banning workers right to strike, allotting land to big businesses and various other measures on the name of creating attractive environment for foreign capital (Patnaik 2000). 


\section{Emerging Market Economies}

Here first I would like to define the concept 'emerging market economies'. The term emerging economy is defined as a country with income per head of population of $\$ 9,265$ or less. With this definition the big and small size countries are included. And these are typically economies in transition, moving from a closed to an open economy, as they seek to integrate into the world economy. The term coined in 1981 by Antoine W. Van Agtmael of the International Finance Corporation of the World Bank an emerging market economy (EME), which is defined as an economy with low-to-middle per capita income (Felton and Reinhart 2008). Such countries constitute approximately $80 \%$ of the global population, representing about $20 \%$ of the world's economies. Hence, even though China is deemed one of the world's economic powerhouses (Arrighi 2007; Siddiqui 2009b; Dyer 2009a; Sachs 2009), it is lumped into the category alongside much smaller economies with a great deal less resources, like Tunisia. Both China and Tunisia belong to this category because both have embarked on development and economic reform programs, and have opened up their markets.

The emerging market economies are characterized as transitional, which means that they are in the process of moving from a closed to an open market economy. The adoption of these policies will suppose to lead to a better economic performance levels, as well as transparency and efficiency in the capital market. It also involves reform in exchange rate system because a stable local currency builds confidence in an economy, especially when foreigners are considering investing. Moreover, foreign investment is seen as a signal that the world has begun to take notice of the emerging market, and when international capital flows are directed toward an EME, the injection of foreign currency into the local economy adds volume to the country's stock market (Wade 1998; Kotz 2008; Siddiqui 2008a; Jacques 2009). According to proponents, for foreign investors the EME provides an outlet for expansion by serving, for example, as new sources of revenue. For the poor countries the employment levels will increase, labour and managerial skills will become more refined. It is claimed that in the long-run, the EME's overall production levels would increase, increasing its GDP and eventually lessening the gap between the developed and developing worlds (IMF 2007).

China adopted neoliberal economic policies in the 1978, while India adopted much later i.e. in 1991. Therefore, both economies are known as emerging market economies because both prior to economic reforms have had closed and centrally planned economies. Figure 1 below illustrates that since the liberalization of economies in China and India their gross domestic product has increased dramatically. However, the increase in growth rates was much higher in China than in India (Note 1). 


\section{Macrothink}

Figure 1. China and India’s Gross Domestic Product Growth

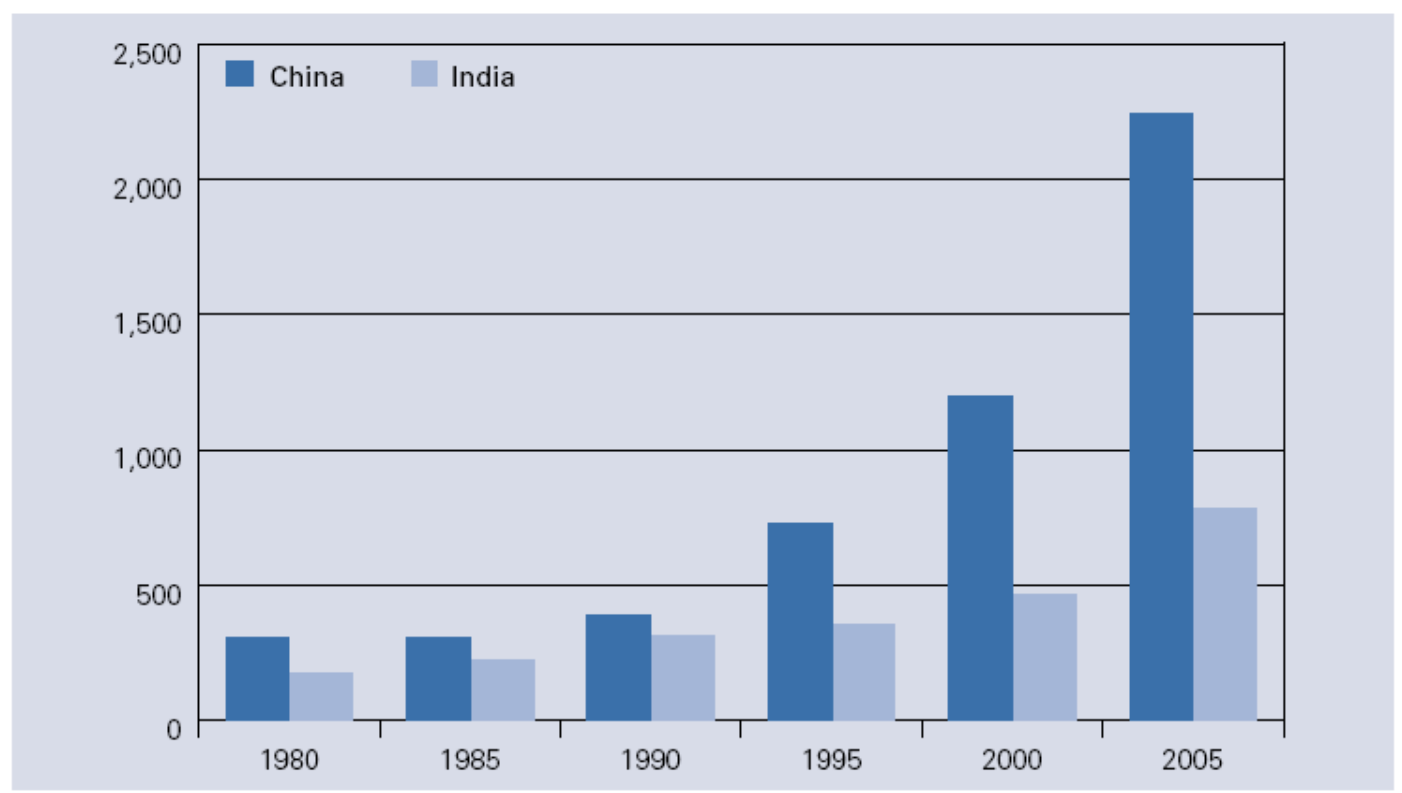

Source: IMF World Economic Outlook

Source: China and India: Opportunities and Challenges for UK Business, 2009. BERR Economic Paper 5, February, London: Department of Business Enterprise \& Regulatory Reform, pp.5

However, it will be interesting to look at the gross domestic production for longer period and also compare it with other countries like Europe and Japan. On the issue of the historical share of world GDP growth, the prominent British economic historian Professor Maddison (2007) has calculated the global GDP for various countries, which are shown below. The Figure 2 illustrates for the last two millennia China and India accounted for about half of the world GDP between them. However, from the 1800s both countries went through a period of relative decline. This period also coincided with the rise of European power and colonization and subjugation of the Asian economies (Note 1) 


\section{Macrothink}

Research in Applied Economics

ISSN 1948-5433

2009, Vol. 1, No. 1: E3

Figure 2. Historical Share of World GDP

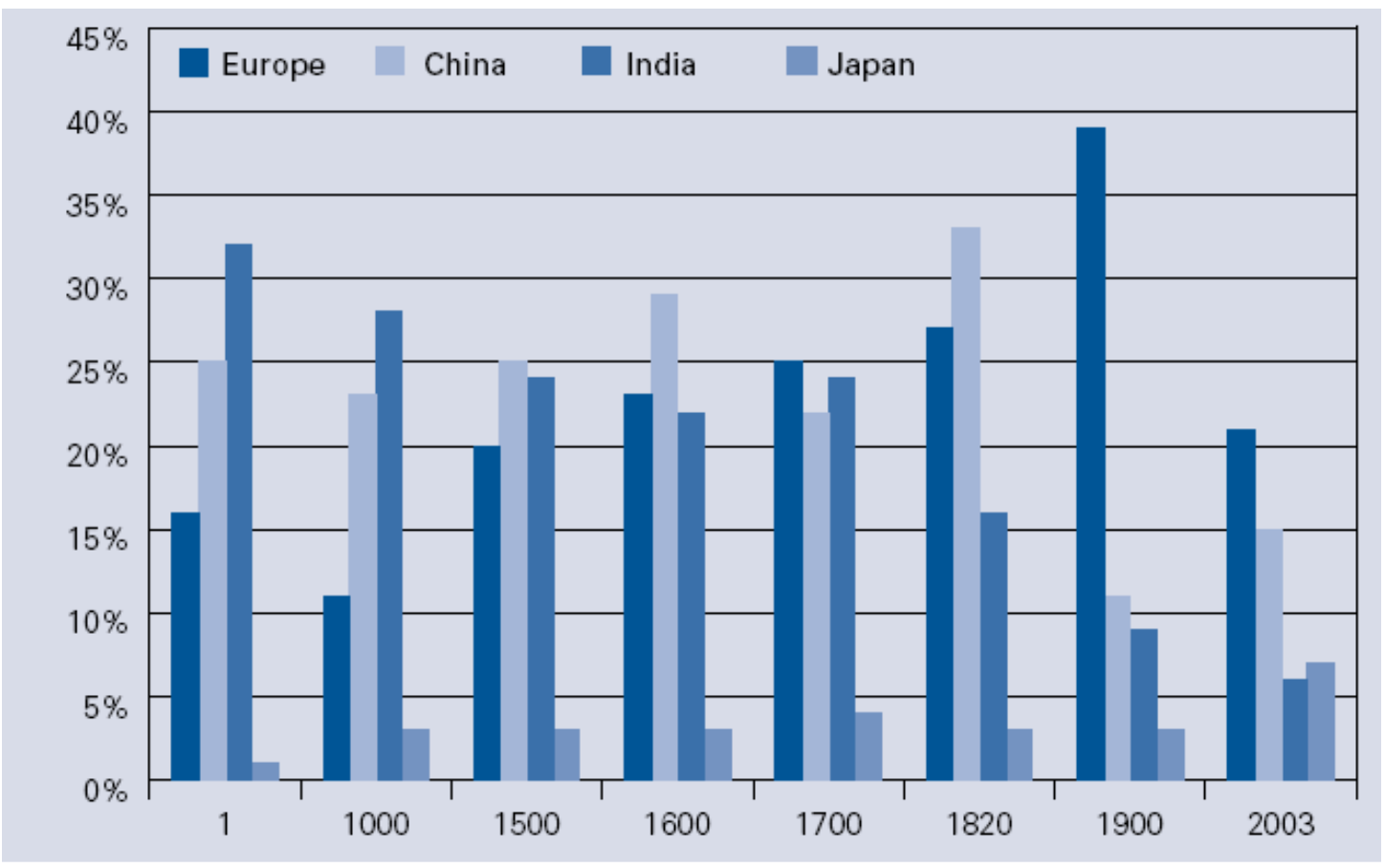

- Source: Maddison 2007; China and India: Opportunities and Challenges for UK Business (2009) BERR Economic Paper 5, page 4, February, London: Department of Business Enterprise \& Regulatory Reform. (http://www.berr.gov.uk)

Figure 3. Projected GDP Growth

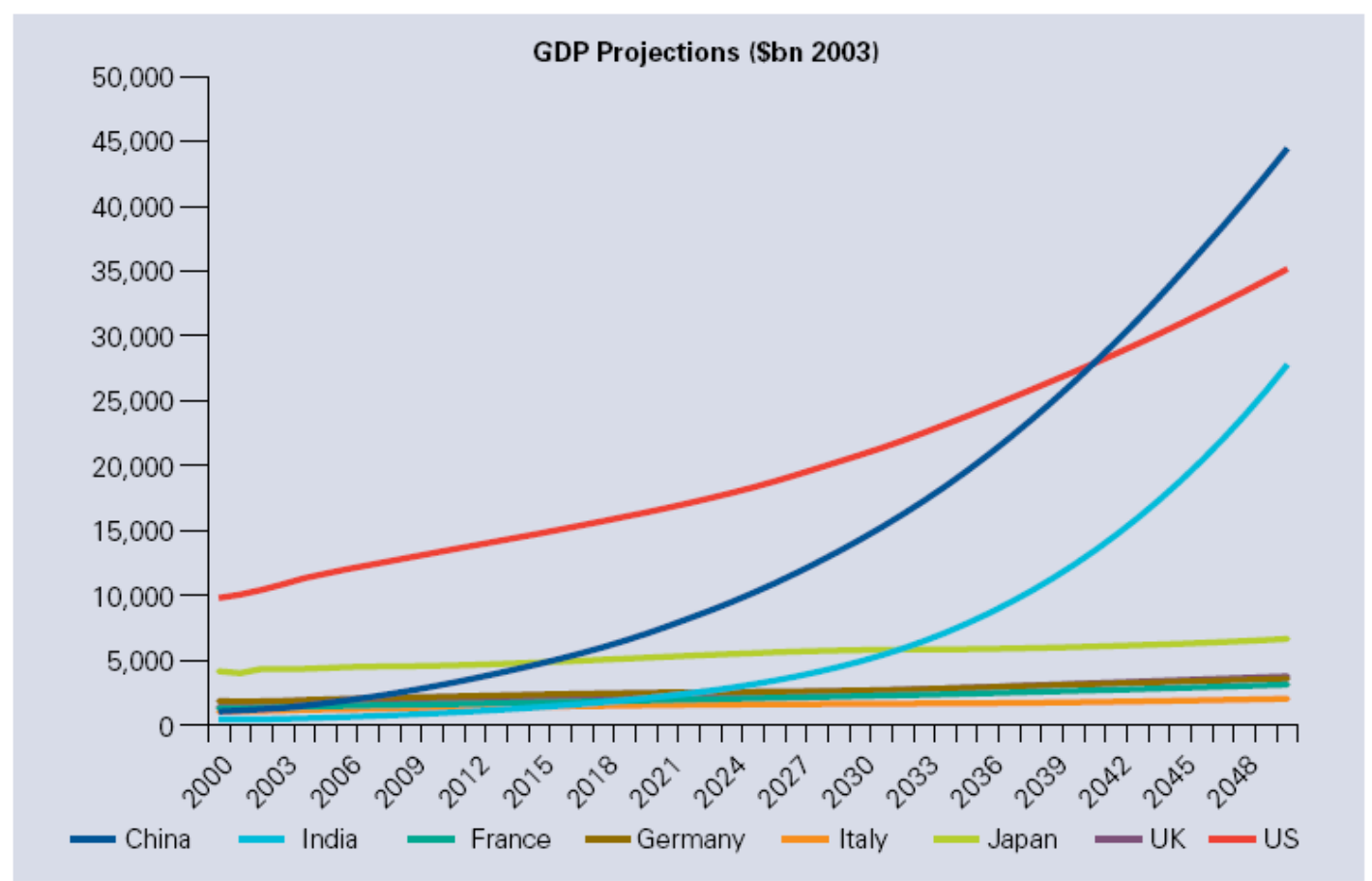

Source: Goldman Sachs, Dreaming with the BRICS (2003)

Source: quoted in China and India: Opportunities and Challenges for UK Business, 2009. BERR Economic Paper 5, February, London: Department of Business Enterprise \& Regulatory Reform, pp 6 
In recent years the rapid economic growth in China and India and its impact of this on the world economy has been crucial in many ways like not only exports have risen from these two countries but also their imports have risen sharply and thus opening new markets for western technology and capital investments. Measured at PPP China and India now account for $10.8 \%$ and $4.6 \%$ of World GDP respectively, compared to $3.3 \%$ for the UK. More importantly, their rapid growth is increasingly shaping world demand; accounting for roughly $30 \%$ of the growth in world GDP since 2000. Both countries carried out 'pro-market' and moved towards greater openness to international trade and investment. Starting in the late 1970s, China's trade with the rest of the world began to rise significantly, with India following suit from the early 1990s onwards. (China and India, BERR, 2009) Between them China and India accounted for over $10 \%$ of the growth in world trade since the 1990s. China's share of world trade has roughly doubled every ten years. India's trade share remained stagnant through the 1980s and 1990s, but has started to rise more rapidly over the last decade (China and India, BERR, 2009).

Figure 4. Projected per Capita GDP Growth

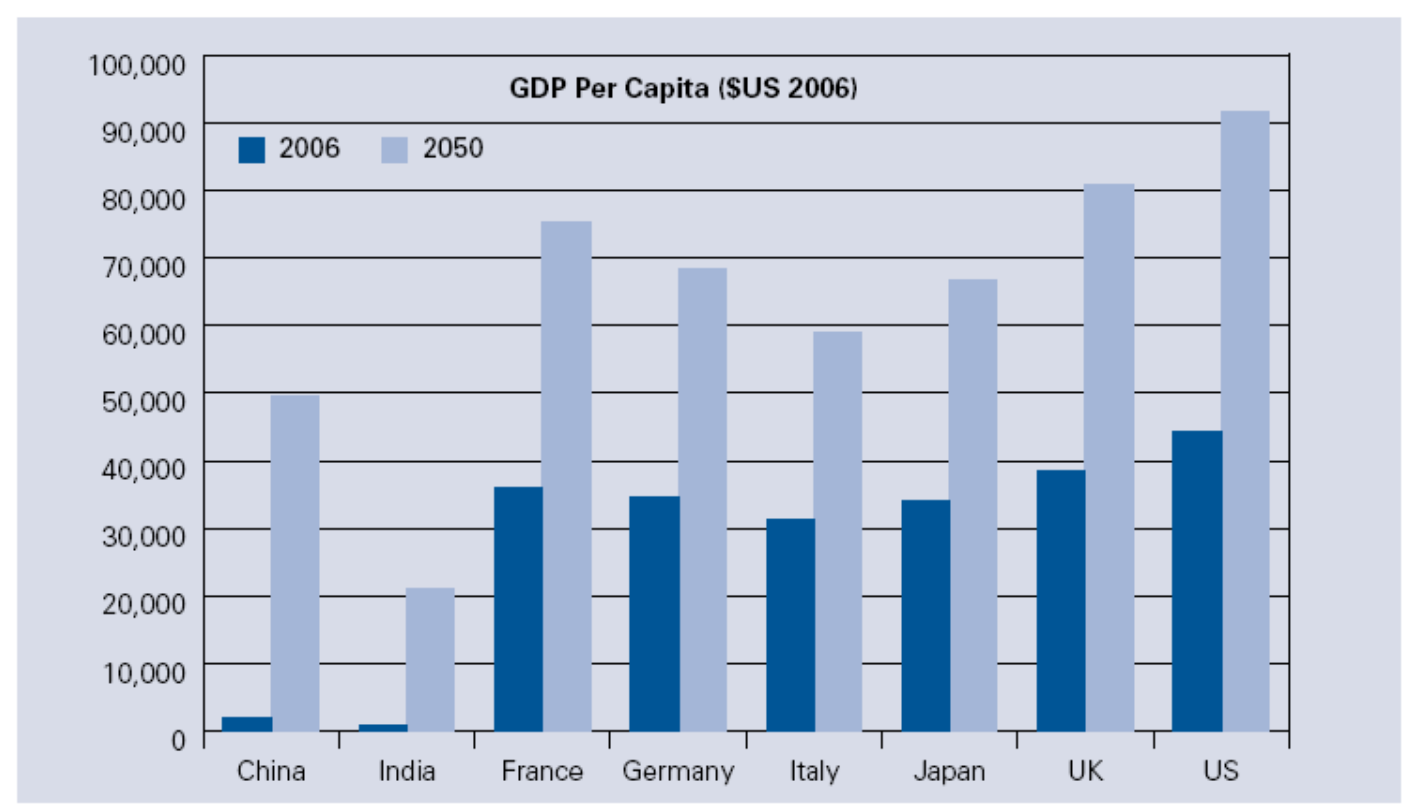

Source: Goldman Sachs, BRICs and Beyond (2007)

Source: also quoted in China and India: Opportunities and Challenges for UK Business, 2009. BERR Economic Paper 5, February, London: Department of Business Enterprise \& Regulatory Reform, pp.7

On the basis of most recent rapid economic growth very optimistic forecasts were made by Goldman Sachs (2003) as Figure 3 illustrates. The high growth rates of China and India is expected to be continued in the coming decades. Goldman Sachs (2003) predicts that China will become the second largest economy in the world by 2016 and go on to overtake the US as the world's largest economy by 2041. India will not be far behind, with its GDP overtaking Japan by 2032. Although these countries will become significant in terms of economic size, their per capita incomes will still be low by the standards of the developed economies. As 
Figure 4 shows that in 2050 China's average per capita GDP is forecast to be only slightly higher than the current level in the US, with the figure for India less than half that. Goldman Sachs estimated that China will overtake USA as the world's largest economy by 2039 and it was said that India will be close behind.

Goldman Sachs (2003) forecasts the Chinese economy will overtake that of the US by 2040 (Quoted by Dyer 2009a:5). The Economist Intelligence Unit says that in terms of purchasing power parity - which adjusts for price differences between countries to reflect actual buying power of local incomes - China will takeover US 2017(The Economist, 2008b; Dyer 2009a). In spite of rapid growth and the rapid transformation of its economy during the last three decades, China remains relatively poor. In the World Bank's rankings of gross domestic per capita for 2007, using purchasing power parity, China was at $122^{\text {nd }}$ place at US\$ 5,370 behind Egypt and El Salvador. By the recent estimate China's GDP was US\$3,382 billion, the US's was US\$13,807 billion and Japan’s was US\$4,382 billion (World Bank 2008).

\section{Decoupling Theory}

On the onset of the global financial crisis in 2007 the international financial institutions claimed that it will have almost negligible impact on Chinese and Indian economies. Similar views were expressed by the mainstream economists, who were talking about "decoupling" of Asia from Western economies. It was argued that China and India had already emerged as alternative routes for the global economy (Nocera 2008; Rodrik 2006). However, recent evidence shows that far from alternative growth routes, China has been worst affected and its exports are down and slowdown in growth has dramatically affected manufacturing employment (IMF 2009; Krugman 2009).

Furthermore, as soon as the crisis became visible in the US the Indian government, for example, reassured both their domestic and foreign investors that their financial system was safely insulated from that of western economies and that the impressive growth many have witnessed was most unlikely to be affected. This was based on so-called "decoupling theory" which was then endorsed by IMF and the influential business magazine namely The Economist (IMF 2007; The Economist 2008a). This theory claimed that growth in Asia was driven by mainly domestic factors and that these factors were decoupled from trends in the West. The growth engines in Asia (i.e. China, India) would not only continue but also serve to shock absorber for the western economies and might even to pull them out of recession (Note 2) (Nocera, 2008).

Initially it was said that China and India, will not be much affected by the financial crisis. Firstly, it was suggested that US slowdown was specifically related to housing sector and would less likely effect the whole economy. Secondly, it was said that trade linkages of the emerging economies with the US had diminished and trade among emerging markets had become more important than in the past. Thirdly, the emerging markets were net savers in the world economy, not borrowers and finally, over the past decades, these economies have had neo-liberal economic reforms, as a result of which they had become more competitive and efficient. IMF (2007) notes “...the potential size of spillovers from the United States has increased with greater trade and financial integration, but that the importance of these links 
should not be overestimated...past episodes of highly synchronized growth declines across the globe were not primarily the result of developments specific to the United States, but rather were caused by factors that affected many countries at the same time... Overall, these factors suggest that most countries should be in a position to "decouple" from the US economy and sustain strong growth if the US slowdown remains as moderate as expected, although countries with strong trade linkages with the United States in the specific sectors may experience some drag on their growth" (IMF 2007).

It seems that in a time of global economic crisis, the higher level of financial integration impacts on the economy in three ways: lowering domestic liquidity, causing stock prices to fall, and reducing companies' access to overseas finance. The fresh international commercial borrowings will become difficult. There will be impact on economy arising from foreign direct investment (FDI) and foreign institutional investment (FII). These inflows have contributed to accretion of foreign exchange reserves. For example, in India, the FII inflows decreased to US\$ 6.6 bn in April-September 2008-09 from \$15.5 billion in the same period in 2007-08. Earlier capital inflows were mostly used not for productive investment by the countries that received them. Instead they used it for external reserve build up, which reflected attempt to prevent their exchange rates from appreciating.

Some argue that China can use the US\$ 2 trillion of foreign reserve to bail out bankrupt US financial system (Jacques 2009; Winters and Yusef 2007; Wolf 2008). But these hopes are misplaced. I find the argument that China emerging as the alterative engine of growth for the world economy will unlikely to happen in near future. This is mainly due to: Chinese growth, which has pulled along with many other East Asian countries is a production chain, has been largely export-led. For example, the US, EU and Japan together account for more than half of China's exports, and as recession deepens, it is bound to affect both exports and economic activity in China. Chinese government is trying to expand internal demand. However, it will not generate levels of international demand that will come anywhere near the meeting the shortfall created by the recession in the West. Moreover, China's share of global imports is still too small for it to serve as a growth engine on the same scale as the US economy.

\section{Falling Growth and Employment}

Growth forecasts are being revised sharply across the Asian region (IMF 2007 and also 2009; The Economist, 2009a and 2009b). According to IMF, the developing economies in Asia, which as a group grew at $10.6 \%$ and $7.8 \%$ in 2007 and 2008 respectively, are estimated to grow only $5.5 \%$ in 2009 (IMF 2009). According to Chinese government figures, more than 20 million rural migrant workers have lost jobs as a result of slowdown in manufacturing output. The decline in growth rates also adversely affected the demand for electricity and raw materials. For instance, electricity production fell by $6 \%$ in 2008, having grown at $15 \%$ on average since 2003, which suggests that Chinese economy has been growing at slower rates than IMF figures of $9 \%$ in 2008. Even the $5 \%$ growth is not enough to keep unemployment down (Wade 2009).

The impact of financial crisis would also be felt towards the cancellation of large investment projects and infrastructures. This will also have negative multiplier effects, as cancelled 
orders and lost employment will further reduce demands. Overall lower market expectations will undermine investors confidence would lead towards further negative impact on overall economy. Tourism and aviation sectors will be hard hit. Also Commodity prices boom will end. The neo-liberal economic reform period although did witness rapid increase in growth in India but this was not accompanied by rise in employment opportunities also described as “jobless” (Note 3) growth. Despite this, expectations were quite high, for instance in India, both within the country and in the international market.

According to IMF (2009) net capital flows to emerging markets will drop to just US\$ 165 billion in 2009, down from $\$ 929$ billion in 2007. Lending from commercial banks is likely to go into reverse (Beattie, 2009). According to IMF revised projection for 2009/10 presented in Chart 1 below indicates that global growth rates will decline sharply to minus rates. It would also mean that the export demands for goods produced by the emerging markets will decline. As a result, it would have adverse affects on employment and income levels in emerging economies such as China and India. For instance, the slowdown in the global GDP growth has constituted by far most important factor constraining India's exports. The OECD countries account for $42 \%$ of India's merchandise exports (Note 4) and nearly entire export of services, with services accounting for $37 \%$ of export earnings (including earnings from invisibles) in 2008. The fall in global GDP and the deep recession in developed countries will constitute a major contractionary factor for the Indian economy (Note 5). It does not mean that we should ignore the growing importance of export to other EMEs whose share in merchandise rose form $30.9 \%$ in 2001-02 to $42.3 \%$ in 2007-08.

Overall the Asian economies, which had become dependent of manufactured goods to the Western markets, are experiencing a sharp fall in the production of export goods and increase in unemployment. For example, Taiwan's export declined by $40 \%$ in December 2008 compared to same month last year. In Indonesia, the fourth most populous country in the world, is experiencing surging of unemployment as the country's export industries are cutting down their output, but also as tens of thousands of migrant workers are coming back after being laid off in neighboring countries like Singapore and Malaysia (Bradsher 2009a and also 2009b). 


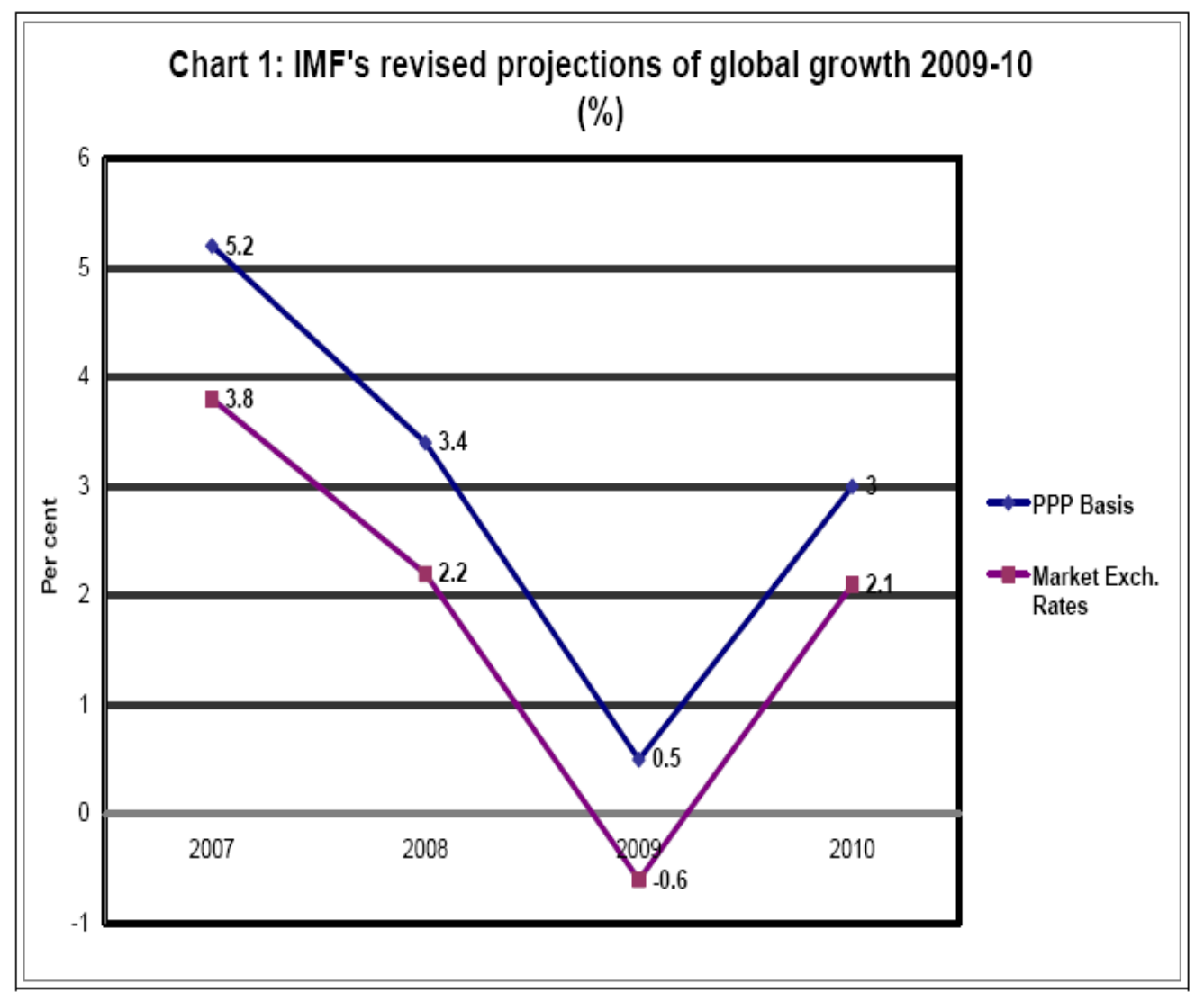

Source: International Monetary Fund (2009) Staff estimates for 2009, January, Washington DC: IMF

It seems that the impact from the global financial crisis is resulting in job losses in various sectors of the Indian economy. However, the aggregate estimate of the extent of the increase in not available. Recently the governments' Labour bureau conducted a sample survey covering eight sectors such as mining, textile, metals and metal products, automobile, gems and jewellery, construction, transport, IT etc. to arrive at an estimate of job loss. The survey was based on limited samples and estimated a loss of half million people (Government of India-Statistical Abstract India 2008). Many people have questioned survey's methodology. Therefore, it seems that the actual decline in employment in 2008-09 will be much higher. The recruitment from elite institutions like IITs and IIMs for overseas market will decline rapidly. The redundancies in software and outsourcing firms will be huge.

In India widespread banking crisis will create a serious credit crunch for traders (Siddiqui 2008a). Instances of banks delaying or not honoring guarantees to traders are becoming more frequent. Indian exporters are finding it increasingly difficult to secure credits. And also with the globalization of the supply chain in production process, a disruption anywhere in the cross-border flow of intermediate inputs tends to create a disproportionately large effect on output and employment. In India, the software among the fastest growing exports, were also likely to be the most affected in the wake of rich countries downturn. The direct impact of the 
global trade slowdown on export industries in India like textiles, gems and jewellery, leather and carpets will be huge. According to IMF, the growth of exports from emerging economies is likely to fall from positive $9.6 \%$ in 2007 to $5.6 \%$ in 2008 to a negative $0.8 \%$ in 2009 (IMF 2009, The Economist 2009b and also 2009c). Besides this, the recession is bound to affect demand, capacity utilisation and employment in manufacturing industries catering for domestic markets. In the neoliberal reforms period the growth has been driven in India by credit financed purchases encouraged by easy liquidity and low interest rates. The curtailment of credits due to cautious financial sector would further reduce demand, increase inventories and lead to job losses. In recent years we have witnessed Indian big corporations is increasingly collaborating with foreign finance capital. These big corporations, although small in numbers, is junior partner of foreign capital and in the entire neo-liberal reform period this partnership is more evident (Girdner and Siddiqui 2008).

The significance of the impact on trade for the domestic economy arises due to: with rapid increase in exports of both merchandise and services lasting until recently (Note 6). As a result massive investment has been undertaken to export-oriented sectors in India in recent years, including special economic zones (SEZs). The sharp drop in export growth thus not only effect an economic slowdown through multiplier process, but will also cause debt default, bankruptcies and will ultimately lead to severe cutbacks in pipeline investments. Also the given share of exports at about $22 \%$ of GDP, the quantitative impact will be far from minimal.

The pattern of production is dictated by the neo-liberal reforms through raising the income of the rich faster than that of the rest of the society. The production structure resulting from this market driven high growth is heavily biased against the poor. While demand expands rapidly for various goods, demand for basic necessities of life hardly expands. Nearly half of the Indian children under 6 years suffer from under weight and malnutrition, while $40 \%$ adults suffer from chronic energy deficit (Patnaik 2009).

Some sectors of the Indian economy had experienced higher growths such as IT, auto industry, pharmaceuticals etc (The Economist 2009a). And also certain sections have benefited with these policies. For example, according to Forbes magazine list for 2007, the number of Indian billionaires rose from 9 in 2004 to 40 in 2007, much richer country like Japan had only 24, France only 14 and China had only 17, The combined wealth of Indian billionaires rose from US\$ 106 billion to 170 billion in a single year 2006-07. This $60 \%$ increase in wealth would not have been possible in India, except through transfer of land from the state to big businesses in the name of development.

The fall out of the current financial crisis can be seen in India's widening of the current account deficit on India's balance of payments from $1.5 \%$ of GDP in 2008 to $3.8 \%$ of GDP during April-September 2009. The reason seems to be that while the export growth is slowing, imports have continued to be the same. Merchandise trade data available till December 2008 indicate that India's aggregate merchandise exports have declined in three months (October-December 2008). While merchandise imports has recorded higher growth of $30.8 \%$ during April-December compared with $27.6 \%$ a year ago. Another crucial area to discus is the effect of the recession on services exports. The net services incomes on the current account of India's balance of payments, which roes from US\$ 14 bn to \$ 18 bn between 
April-September 2006 and April-September 2007, registered a further rise to US\$ 22.9 bn during April-September 2008 (Government of India-National Accounts Statistics 2008). The effect of the crisis would be on the renewal of contracts and the signing of new contracts. This would mean when the data for whole year becomes available the slowdown may be greater.

The disproportionate dependence on capital flows, which is substantial in the form of portfolio capital, is a recent development. Foreign investment flows increased rapidly from US\$ 4.9 bn in 1995-96 to \$ 29.2 bn in 2006-07 and then more than doubled to $\$ 61.8$ bn in 2007-08. This dramatic increase was largely due to the relaxation of sectoral ceilings on foreign shareholding and the further liberalization of rules governing investments and repatriation of profits from India (Siddiqui 2009b). We must not forget that liberalization of the economy began in 1991 whereas the sharp rise in foreign investment flows occurred only recently (Chandrasekhar and Ghosh 2004). I also find that the experience in the Asian emerging markets as a group was very different. For example, the net direct and portfolio equity investment into Asian emerging markets (China, India, Indonesia, Malaysia, Philippines, South Korea and Thailand) declined from US\$ 122.6 bn in 2006 to \$112.9 bn in 2007 and an estimated \$ 57.9 bn in 2008. This implied that private investors in equity were pulling out of emerging Asian markets as group at a time when their investments in India were rising. This increased the possibilities of uncertainties in future they will pull out quickly as happened in 1997 during the East Asian financial crisis (Wade 1998; Kotz 2008; Sachs 2009).

A weakening of the demand for Indian exports in US and EU will affect IT and Business Process Outsourcing (BPO) sector and also a loss of opportunities for young persons seeking employment at lucrative salaries abroad. In India now IT sector which earned US\$ 50 bn annually is expected to fall by $50 \%$ of its total revenues. It is now estimated that sluggish demand for exports would result in a loss of 10 million jobs in Indian export sector alone. Exports which accounted for $22 \%$ of the GDP are expected to fall by $12 \%$. As against US package of US\$ 800 bn to failing US economy, the Chinese package of \$580 bn to salvage its economy, the Indian fiscal package of $\$ 7.3 \mathrm{bn}$ is a small measure to boost the economy.

The Table 1 shows economic data of the former G7 countries and emerging economies. The external debtor position of both private and public debt is very high for UK, France and Germany between $150 \%$ and $450 \%$ of the GDP range, is followed by the US in the $90 \%$ of GDP range. Contrary to China shows very high rate of foreign currency reserve and very small proportion of debt GDP ratio as indicated in Table 1. 
Table 1. High Indebted Countries comparative indexes December 2008

\begin{tabular}{|l|l|l|l|l|l|}
\hline & $\begin{array}{l}\text { International } \\
\text { Reserves }\end{array}$ & $\begin{array}{l}\text { Growth } \\
\text { Perspective } \\
2009\end{array}$ & GDP (PPP) & $\begin{array}{l}\text { Public } \\
\text { Debt/GDP } \\
* *\end{array}$ & $\begin{array}{l}\text { External } \\
\text { Debt/GDP } \\
* * *\end{array}$ \\
\hline & $\begin{array}{l}\text { (Billions } \\
\text { US\$) }\end{array}$ & $(\%)$ & (trillions US\$) & $\%$ & $\%$ \\
\hline USA & 70.57 & -1.6 & 14.58 & 74.90 & 93.42 \\
\hline Canada & 41.08 & -1.2 & 1.34 & 62.3 & 56.74 \\
\hline UK* & 57.30 & -2.8 & 2.28 & 47.20 & 458.53 \\
\hline Germany & 136.20 & -2.5 & 2.86 & 62.60 & 156.79 \\
\hline France & 115.70 & -1.9 & 2.10 & 64.40 & 209.63 \\
\hline Italy & 104.00 & -2.1 & 1.80 & 103.70 & 58.86 \\
\hline Japan & 954.10 & -2.6 & 4.49 & 170.40 & 32.25 \\
\hline China & 2033.00 & 6.70 & 7.80 & 15.70 & 5.38 \\
\hline Brazil & 197.40 & 1.80 & 2.03 & 40.70 & 11.63 \\
\hline Russia & 435.40 & -0.70 & 2.23 & 6.80 & 23.69 \\
\hline India & 274.20 & 5.10 & 3.32 & 59.00 & 4.91 \\
\hline Taiwan & 280.90 & 0.89 & 0.76 & 28.20 & 13.08 \\
\hline South Korea & 231.20 & 0.70 & 1.31 & 27.20 & 19.05 \\
\hline Singapore & 170.10 & -2.50 & 0.24 & 92.60 & 10.25 \\
\hline
\end{tabular}

Source: IMF, January 2009 Report; US Treasury, 2009 and also www.OBELA.org@IIEC UNAM (accessed on $30^{\text {th }}$ March 2009)

Notes:* UK, its external debts is estimated to December 2007

** Public debt is measured in domestic currency

***External debt includes private and public debt in foreign exchange

The IMF' s World Economic Outlook (WEO) notes that "Financial market condition have remained extremely difficult for a longer period than envisaged in November 2008 WEO update, despite wide ranging policy measures to provide additional capital and reduce credit risks” (IMF, November 2008). Growth estimates for 2008 and projections for 2009 and 2010 have been scale down considerably vis-à-vis the November 2008 update. The advanced economies are estimated to have grown at $1.0 \%$ in 2008 and projected to grow at $-2 \%$ in 2009 and $1.1 \%$ in 2010. As far as the Asian emerging market economies the growth of ASEAN-5 at $2.7 \%$ in 2009 and $4.1 \%$ in 2010 (in contrast to 6.3 and $5.4 \%$ in 2007 and 2008 respectively) of China $6.7 \%$ in 2009 and $8 \%$ in 2010 (13\% and $9 \%$ in 2007 and 2008 respectively) and of India at $5.1 \%$ in 2009 and $6.5 \%$ in 2010 (9.3\% and $7.3 \%$ in the previous two years) (Note 7). 


\section{Export-led Growth Model}

The adoption of neoliberal policy will suppose to increase the inflows of FDI and export of goods and services. Since 1980 the Inflows of FDI into China represent the most significant flows, not only in capital but also technological and managerial capabilities. The unprecedented rise of FDI into China was about US\$ 60 bn a year. Moreover, in 2008 China also began to export capital e.g. it lends the US more than US\$ $400 \mathrm{bn}$, equal to more than $10 \%$ of China's GDP (Dyer 2009b), which was just unthinkable a decade ago. Table 2 shows increase in inward and outward investments for the last three years for several countries. In China, for example, the inward investment within this period almost doubled, while China also begin to invest outwards although it is very modest compared to West. For India the inward investment has risen but at slower rates. For the developed countries both inward and outward investment increased between 2003 and 2005.

Table 2. Inward and Outward direct investment flows in US \$ bn

\begin{tabular}{|l|l|l|l|l|l|l|}
\hline & \multicolumn{2}{l}{ 2003 } & \multicolumn{2}{l}{ 2004 } & \multicolumn{2}{l}{ 2005 } \\
\hline & Inward & Outward & Inward & Outward & Inward & Outward \\
\hline $\begin{array}{l}\text { China } \\
\text { Mainland }\end{array}$ & 47.8 & -0.15 & 54.94 & 1.81 & 79.13 & 11.31 \\
\hline France & 42.50 & 53.15 & 38.71 & 76.65 & 70.69 & 133.60 \\
\hline Germany & 29.20 & 6.17 & -15.11 & 1.88 & 32.66 & 45.63 \\
\hline $\begin{array}{l}\text { Hong } \\
\text { Kong }\end{array}$ & 13.62 & 5.49 & 34.03 & 45.72 & 33.62 & 27.20 \\
\hline India & 4.59 & 1.33 & 5.47 & 2.02 & 6.60 & 1.36 \\
\hline Japan & 6.24 & 28.77 & 7.80 & 30.96 & 3.21 & 45.44 \\
\hline Russia & 7.96 & 9.73 & 15.44 & 13.78 & 14.60 & 13.13 \\
\hline Taiwan & 0.45 & 5.68 & 1.90 & 7.15 & 1.63 & 6.03 \\
\hline UK & 16.78 & 62.19 & 56.21 & 94.86 & 164.53 & 101.10 \\
\hline USA & 53.15 & 129.35 & 122.40 & 222.44 & 99.44 & -12.71 \\
\hline
\end{tabular}

Source: UN World Investment Report 2006, National sources

FDI - firms can invest via FDI including joint ventures, exclusive foreign-owned enterprises, merger and acquisition (M\&A).

Moreover, the scale and speed of economic growth in China overall, and specific improvements in the innovative capabilities and competitive advantages of particular Chinese firms, are connected to these FDI inflows. The unprecedented rise of FDI into China was about US\$ 79 bn a year recently - has created large array of mergers and acquisitions and alliances. In the past 25 years, GDP growth averaging more than 9\%, China has moved away 
from the closed system towards an open market-oriented economy (Rodrik 2006).

James Fallows (2009) in his recent works “China's Way Forward” offers an assessment of China's economic prospects and reflects comparatively on the experience of US and Japan. He finds that China's industrialisation and export-dependent economy will be hard hit by this current crisis. However, Fallows concludes that China, despite millions of migrant workers returning to countryside where by they face protracted unemployment, will not only weather the storm, but is likely to emerge stronger from it. He suggests various reasons for such optimism e.g. unlike deficit nations such as US, China has vast surpluses and it is vigorously allocating part of them to boost production and reduce unemployment. The country has also embarked on massive labor retaining programs. As Bradsher (2009b) reports recently from Guangdong province alone has begun to implement three-to-six months training programs to train four million workers. The low wages paid to trainees are part of process that is helping Chinese product to be competitive when the demand for export increases again.

Nevertheless, the short term prospects are not so good. China's Iron and Steel Association recently projected an $80 \%$ fall in 2009 in steel exports. History can provide some clues to the future (Bradsher 2009a). Comparing China today with the US of 1920s, when the country taking advantage of World War I, transformed its trade deficit and emerged as a manufacture house and major creditor nation of the world. During the Great Depression of 1930s the US witnessed high unemployment than Japan and Europe, yet it emerged as global economic power. China today, despite the burgeoning manufacturing and a huge trade surplus, faces five times the trade dependency than the US in the 1930s (Fallows 2009). Fallows cites the specific character of China's partial proletarianisation, which lies behind its dramatic surge in manufacturing output, particularly in export sector. According to him key to this success is the dynamic role played the about 130 million migrant workers who have fuelled China's low wage industrialization while retaining land ownership right in their villages (Fallows 2009).

Table 3. Economic Growth in China

\begin{tabular}{|l|c|c|c|c|c|c|}
\hline & $\mathbf{2 0 0 3}$ & $\mathbf{2 0 0 4}$ & $\mathbf{2 0 0 5}$ & $\mathbf{2 0 0 6}$ & $\mathbf{2 0 0 7}$ & 2008* \\
\hline $\begin{array}{l}\text { Nominal } \\
\text { GDP } \\
\text { (US\$ bn) }\end{array}$ & 1,641 & 1,932 & 2,247 & 2,632 & 3,131 & 3,673 \\
\hline $\begin{array}{l}\text { GDP Per } \\
\text { capita } \\
\text { (US\$) }\end{array}$ & 1,270 & 1,486 & 1,719 & 2,001 & 2,366 & 2,759 \\
\hline $\begin{array}{l}\text { GDP } \\
\text { growth } \\
\text { (real } \\
\text { in \%) }\end{array}$ & 10 & 10.1 & 10.2 & 10.7 & 10.7 & 10.0 \\
\hline
\end{tabular}

Source: Deutsche Bank Research, 2008

(www.dbresearch.com/srvlet/reweb2.ReWEB?rwkey=u6025395)

Note: * estimated one

Chinese GDP has increased more than 10 fold since 1978. Nominal GDP tripled within the 
last five years in China as the above Table 3 shows. With the same period in per capita income rose to impressive levels. However, despite impressive growth rate, in per capita terms the country is still lower-middle income and 130 million Chinese still live below poverty line.

Chinese international trade in goods as a percentage of GDP doubled between 1990 and 2002. The largest contribution was made by manufacturing sector. In 2006, China's international trade volume reached US\$2.22 trillion, with an increase of $24 \%$. China now ranks $3^{\text {rd }}$ in the world in terms of total export and import volume. Table 4 provides us the main destinations of items of the export and import commodities. About $21 \%$ of Chinese goods exported to US markets, Hong Kong and Japan are quite important export destinations of Chinese goods. Regarding imports, China imports largest amounts from Japan followed by South Korea and Taiwan, while US is in the fourth place. Comparison with Japan during rapid growth period, Chinese exported a great deal more across wider range of industries than Japan did during its peak growth period. China had surpassed Japan to become the third-largest trading nation after US and Germany. In 2006 China's trade surplus tripled to boost foreign currency reserves more than Japan.

Table 4. China Trade Data - main destination in 2006

\begin{tabular}{|l|l|l|l|}
\hline $\begin{array}{l}\text { Main } \begin{array}{l}\text { Pestinations of } \\
\text { exports }\end{array} \\
\text { United States }\end{array}$ & $\begin{array}{l}\text { Percent } \\
\text { total }\end{array}$ & $\begin{array}{l}\text { Main } \\
\text { destinations of } \\
\text { imports }\end{array}$ & $\begin{array}{l}\text { Percent of } \\
\text { total }\end{array}$ \\
\hline Hong Kong & 16.0 & Japan & 14.6 \\
\hline Japan & 9.5 & South Korea & 11.3 \\
\hline South Korea & 4.6 & Taiwan & 11.0 \\
\hline Germany & 4.2 & United States & 7.5 \\
\hline Netherlands & 3.2 & Germany & 4.8 \\
\hline UK & 2.5 & Malaysia & 3.0 \\
\hline Singapore & 2.4 & Australia & 2.4 \\
\hline
\end{tabular}

Source: The Economist, Country Profiles, 2009

\section{(www.economsit.com/countries/china/profile.cfm?folder=profile-FactSheet)}

Exports of good and services will be affected by global economic downturn. For most of the emerging economies, the US and the EU remain the important sources of export demand and current recession has witnessed that their exports to these markets declined sharply. In the past when money stopped flowing in precipitated financial meltdown - examples of East Asia and in Russia in 1990s and in Latin America a decade earlier clearly shows this. The process of financial liberalization started later in Asia than it did in Latin America. Its adverse effects on macroeconomic polices was seen during the severe financial crisis South-East Asian economies during the 1997. In India neo-liberal economic reforms began in 1991 with a program of stabilization and structural adjustment on behalf of IMF and World Bank. The 
government took measures of macroeconomic stabilization, fiscal correction and inflation controls. Besides it, government also undertook structural reform measures such as industrial deregulation, liberalization of foreign direct investment, privatization, and trade.

Moreover, the financial liberalization across the developing countries has made capital markets much more integrated through mobile capital flows. The short-term implication is the impact on private capital flows to emerging markets which are likely to reduce with the credit crunch and with reduced demand for higher risk investments. During the last five years there was a dramatic increase in capital flows into emerging economies. And this resulted in huge accumulation of foreign exchange reserve. These reserve were used to prevent their exchange rates form appreciating and to build a cushion against potential crises.

After adoption of neoliberal policies there was a sharp increase in foreign investment flows to the region, including inflows of portfolio capital. The operations of foreign firms including banks and insurance companies rule were liberalized, which led to the far excess of capital inflows to the region of that needed to finance the current account deficits. These reserves were invested in "safe" and liquid assets such as US Treasury bills. The foreign capital inflows to Asian markets were not used to finance domestic investment because domestic savings rate were adequate to meet investments in these economies. However, foreign capital inflows financed local demands housing markets, automobiles and durable consumption.

In East Asia the inflows of foreign capital increased, particularly after Plaza accord of 1985, the accord caused a rise in the value of Japanese yen against US dollar (appreciation of yen). As a result, the Japanese exports became expensive overnight and Japanese firms sought a new cheaper production sites and East Asia was the obvious choice - cheap and well educated work force, close to Japan. Japanese government supported capital export to the region, which led to the export-boom in South East Asia. And the rising exports supported more borrowing, more equity issues and thus greater demands for FDI. Capital flows to Indonesia, Malaysia, Philippines, Thailand and South Korea rose form US\$ 47 bn in 1994 to US\$ 93 bn in 1996 (Wade 1998; Dunning 2001). These inflows to the region were premised on the assumption that the exchange rate would hold. If the value of domestic fell the advantages might disappear. Moreover, these countries have undergone financial deregulation during the 1990s. The deregulated financial systems enabled inexperienced private banks and local firms to borrow large amounts. The current globalization has led to increasing concentration of assets in the hands of finance and business along with a phenomenal increase in speculative activities. And also privatization and liberalization has meant the withdrawal of state intervention in economic activities and dismantling of market regulations. The noble prize winner US economist Joseph Stiglitz (1997) then implicitly criticized the IMF approach and solutions to the East Asian crisis: "For the past 25 years East Asian economies have grown more than twice as fast as the average rate for the rest of the world... These successes have been fostered by sound fiscal policies, low inflation, export driven growth, and effective institutions, which in turn helped make East Asia the world's leading recipient of foreign investment. Moreover, the region's high saving rate, more than one third of gross domestic product, is six times foreign investment. These savings have made possible a high and increasing level of investment. Recent development, however, underscore the challenges presented by a world of mobile capital even for countries with 
strong economic fundamentals. The rapid growth and large influx of foreign investment created economic strain. In addition heavy foreign investment combined with weak financial regulation to allow lenders in many Southeast Asian countries to rapidly expand credit, often to risky borrowers, making the financial system more vulnerable”.

\section{Crisis of Neo-liberalism}

The Anglo-American model of capitalism widely known as the neo-liberal or free market ideology, which has dominated the western economic thinking for the last more than a quarter. This theory is based on the dominance of international finance and which has shaped western governments' opinion in favor of policy regimes which benefit finance (Harvey 2006; Glyn 2006). Neo-liberalism contains three main components such as enforcement of "sound finance” through avoidance of significant fiscal deficits, trade liberalization and financial liberalization. The recent financial crisis has certainly destroyed the credibility of the neo-liberal ideology (Harvey 2006).

The proponents of 'free trade' assume that such policy improves welfare (Bhagwati 1966; Fischer 1997). However, it is based on many unrealistic assumptions such as perfect competition, production under constant returns to scale and full employment. The deficiencies in the theoretical basis for the neo-liberal economic policy paradigm are becoming widely recognized that the empirical evidence does not support it. For many developing countries following the 'free trade' has resulted in disastrous consequences and also because free trade could there by cause the economy to get locked into a pattern of production that less progressive and does not provide increasing returns, meaning lower income gains over time.

On the name of privatization in the developing countries, Latin America sold more by value than any other region since 1980s. External influence have had significant influence and therefore it was a political decision to expel the state from business, as deeply indebted states enacted the structural reforms demand by the IMF in order to obtain new loans (Glyn 2006).

The term globalization is defined as the adoption of the policies of liberalization, deregulation and privatization as well as ideology of laissez faire.

Trade liberalization is very important part of the neoliberalism. The question arises why Britain was so much interested in the adoption of so-called 'free trade' policies. On the issues of trade and foreign investment liberalization Friedrich List (1983) argues in the early $19^{\text {th }}$ century that the theory is heavily biased and unsound. According to him, this expresses the interests of industrial countries which have established a lead in manufacturing. Karl Marx (1961) in a lucid explanation on why British manufacturing capital demanded so early such as strong urge to export and drive towards foreign markets. He emphasized that due the narrowness of British home market, economies of scale associated with steam engine and the increase in productivity stemming from the better organization at work in new factories. Once the capital accumulation had grown to the point capital and not only goods had to be exported. This dimension of outwards economic expansion rapidly increased its importance and helping them to consolidate in the form of structural features of the world economy.

John Maynard Keynes have already found capitalist market economies if they are allowed to 
function without government stimulus and regulations that prevent excesses, are inherently unstable, prone to boom and bust as well as to persistent unemployment (Keynes 1949; Robinson 1965). The Keynesian revolution did more than to create discipline of macroeconomic polices, but it also provided a regulated policy framework in the developed countries. Finally, it appears to be clear failure of economic model of neo-liberalism. The notions that markets know best and that self-regulation is the best form of financial regulation have been completely exposed. It is not just on macroeconomic policy where double standard is applied, but for example, the rich countries have been advising the developing countries to adopt "free trade" (Girdner and Siddiqui 2008). If we look at the UK and the US history (Note 8), we find that hey had used protectionism (Note 9) when they were developing countries.

It is useful to look at another detailed study of government policy on the early period of industrialization in Britain. Polanyi (1944) describes the industrial revolution in England of the late $18^{\text {th }}$ century and $19^{\text {th }}$ century, which took place within a thoroughly commercial though not yet thoroughly market-organized economy. Markets places where goods were bought and sold. They were human interactions organized by price, quality, and quantity of traded goods and services. During this period Britain had quite thoroughly commercialized: cottage industries, paid agricultural labor, and thriving trade in towns meant that most people earned money and exchanged money to buy the goods. However, as Polanyi also noted, control and regulation of markets by governments and other organizations were also widespread and common. Moreover, a rapidly expanding factory system altered the relationship between commerce and industry. Polanyi describes how, in spite of the threat to social order, the philosophy that came to be called "laissez faire" was "[b]orn as a mere penchant for non-bureaucratic methods...[and] evolved into a veritable faith in man's secular salvation through a self-regulating market" (Polanyi 1944:135). He provides various examples of state intervention in Britain such as the enclosures of the 1790s, the Poor Law Reform of 1834, the Bank Charter Act of 1844 and the repeal of the Corn Laws in 1846 (Polanyi 1944).

The mainstream economic historians ignore, for example, that how under the name of 'free trade' the process of modernization and commercialization were accompanied by pauperization and famines in large part of India, particularly in Bengal state under British colonial rule (Macalpin 1983; Kumar and Desai 1983; Simmons 1985). According to report of the famine commission in period of 90 years, from 1765 when the British East India Company took over the diwani (rent collection tasks) of Bengal to 1858, Bengal experienced 12 famines and four sever scarcities (Damodaran 2007). The famine of 1770 was occurred by partial mansoon failure. The colonial administration was more concerned about the collection of revenue than about mass death of rural population due to hunger. Bengal population was estimated to be then around 30 million people and one-third of the state population officially admitted to have perished in 1770's Bengal famine (Damodaran 2007; Davies 2001; Hunter 1872). Hunter examined Bengal famine of 1770 a century later on the basis of official records and notes: "the peasant sold their cattle; they sold their implements of agriculture, they devoured their seed grain, they sold their sons and daughters, till at length no buyer of children could be found, they ate the leaves of trees and grass of the field and in June 1770, 
the resident at the Darbar affirmed that the living were feeding on the dead" (Hunter 1872:21).

Another example I will cite here, where colonial administration strictly followed the policy of "free trade" and not to intervene in the economic affairs. In 1943-44 another Bengal famine killed an estimated 4 million people (Greenough 1982; Davies 2001). The colonial administrators on the name of "free trade" introduced ruthless economic agenda in India, which undermined indigenous Indian economy (Siddiqui 1990b). The colonial government disinclination to respond with urgency to food deficits resulted in several appalling famines in India. During the famine year of 1943-44, the colonial administration acquired food for soldiers and industrial cities such as Calcutta and for export to other parts of the empire. Meanwhile the loss of supply of rice from Burma and the government's ineffective control over hoarding and speculation led inevitably to dramatic price increases. As a result, price of rice, staple food for the region, in Dacca rose to four folds within three months in 1943. During the famine, Winston Churchill repeatedly opposed food imports for India and especially intervened to block provisions of 10,000 tons of grain offered by Canada. The British government rejected the request to ask US and United Nations Relief and Rehabilitation Administration (UNRRA) for food assistance (Damodaran 2007; Sen 1981; Habib 1975). During the famines exports of grain was permitted on the ground of non-intervention in trade policy i.e. “free trade” (Bagchi 1976; Siddiqui 1996).

As Professor Sen (1981), noble prize winner economist, concluded that "colonial authorities failed to understand that the famine was not caused by an overall food shortage, and that the distribution of food was not just a matter of railway capacity, but of providing free famine relief on a massive scale.... The Raj [British colonial rulers] was, in fact, fairly right in its estimation of overall food availability, but disastrously wrong in its theory of famines" (Sen 1981:80-83). On the question of 'free trade' Nicholas Dirks (2006) emphasis that the "The fundamental significance of 'free trade' and the idea of an open economy emerged in relationship to a history of monopoly capital in the imperial theatre, which facilitated the substitution of the extra-economic controls of a colonial state for the earlier monopoly guarantees made to a national trading company.... and dependence on the role of empire in capital accumulation and the broad array of opportunities, influences, and resources from greater world” (Dirks 2006:331).

In recent years, the priority given to exports over domestic markets is strong and possibly more accentuated in 'emerging markets', where the so-called successful industries are further factor of economic dualism. This is due to burden of foreign debts and increased pressures by the IMF to export more in order to repay the debts. Also it is related to the fact that the skewed pattern emerging from due to insufficient domestic demand. For instance, In Brazil the agro-food corporations are flourishing while malnutrition is rife and children are dying in one of the 'bread basket' of the world. Professor Bush (2007) in his study of the impact of two decades of neoliberal policy in sub-Saharan African countries, argues that "Although trade. Debt relief and development initiatives are important, they do not alter the structure of the global economy and the poverty that is created by the process like privatization, trade liberalization and market reform” (Bush 2007: 23). 


\section{Conclusion}

Finally, I find that the deceleration in the growth rates in the developed countries due to financial crisis will have major impact on the emerging economies namely China and India. For example, India's industrial output declined sharply to minus $2.3 \%$ growth in March 2009. Within this, the manufacturing sector, which has nearly 80 per cent weight in the Index of Industrial Production (IIP) fell by minus 3.3 per cent. Notwithstanding the government claims made regarding India's GDP growth rates by the government, the global economic prospects (GEP) has estimated the current growth rate this year to be 5.5 per cent projected to fall to 4 per cent next year. This will have further devastating impact on employment, this sharp fall in the growth rate will increase the level of poverty in India with the GEP estimating that India is now only ahead of Sub-Saharan Africa in terms of population below the poverty line with over a quarter of Indians "living in extreme poverty" living on less than US\$1.25 a day.

For the last decade the rapid increase in growth rates in the economies of China and India have given a lot of expectations both domestically and globally. Any decline in growth rates will not only increase unemployment but create explosive situation for instance, in terms of urban vs rural and regional differentiation as growth slows down. I mean high expectations caused by twenty-five years in the case of China and seventeen years of high growth rates of India. Economic growth is precipitating social change and increasing internal tensions between people and regions. As the economy slows down social unrest will increase. Some argue that China can use the US\$ 2 trillion of foreign reserve to bail out bankrupt US financial system (Jacques 2009; Winters and Yusef 2007; Wolf 2008). But these hopes are misplaced. I find the argument that China emerging as the alterative engine of growth for the world economy will unlikely to happen in near future. This is mainly due to: Chinese growth, which has pulled along with many other East Asian countries is a production chain, has been largely export-led. For example, the US, EU and Japan together account for more than half of China's exports, and as recession deepens, it is bound to affect both exports and economic activity in China.

The FDI in India has been estimated to have declined by $55 \%$ - from US\$ 4.4 billion in March 2008 to \$2 billion in March 2009. India's exports have declined for the seventh consecutive month in April 2009 amounting to a fall of 33 per cent.

The proponents of neoliberal economic policies argued that it will increase the amount of FDI inflows and also rise in exports will create jobs and improve living conditions in the developing countries. It seems that the current global financial crisis has witnessed a clear failure of the economic model of neoliberalism. The notions that market knows best, and that self-regulation is the best form of financial regulation, have now been fully exposed for the how far they are from real world and empirically wrong.

It will be useful to briefly summarize the East Asian financial crisis of the 1997. During the 1996 East Asian crisis they were advised by IMF \& World Bank to cut government spending and run budget surplus to $1 \%$ of GDP (South Korea), they have to 'tighten the belt'. These countries also had to raise interest rates to 30 - 50 \% (Stiglitz 1997; Wade 1998). During the 1997-98 Indonesia's financial crisis(Note 10) the IMF advised that the country has to adopt to 'market-friendly' policies, which was earlier given to most the countries in Latin America 
and Sub-Saharan (i.e. Structural adjustment programs) with disastrous outcomes (Williamson 1994). In order to pay off debts they were advised to privatize their national assets so that the foreign investors can buy it at lower prices in Indonesia. At the same time the interest rates were raised to slow down their economy. This resulted in increasing the interest payments on both domestic and international borrowing, which brought misery to large section of the population. During the financial crisis in East Asian countries, the IMF advised that they should run budget surplus and the government spending should be cut down.

However, the Western countries during their current financial crisis are not following the similar polices, which they imposed on East Asian economies in the 1998. For instance, the budget deficit is US is estimated around $12 \%$ of GDP in 2009. Interest rates are reduced to almost zero to stimulate the economy. The governments are not privatizing, but is bailing them out. It appears quite clearly that one sets of policy for poor countries e.g. free market/monetarism, while Keynesianism for rich countries. I mean the Western countries follow Keynesian polices, while suggest free market for the developing countries in similar economic crisis (Note 11). The important lessons from the IMF's East Asian rescue plan the developing countries took was that not to be in a situation where they were forced to turn to IMF for help. Therefore, they decided to accumulate massive amounts of foreign reserves as a defense mechanism.

\section{Acknowledgement}

I would like to thank Dr. Hugo Radice and Dr. Malcolm Chapman for their helpful suggestions and comments. A shorter version of this paper was presented in a research conference on 'The Current Global Financial and Economic Crisis' at the University of Huddersfield, $30^{\text {th }}-31^{\text {st }}$ March 2009.

\section{References}

Arrighi, Giovanni (2007) Adam Smith in Beijing: Lineages of the Twenty-first Century, London: Verso.

Bagchi, A.K. (1976) "De-industrialization in India in the nineteenth century: some theoretical implications”, Journal of Development Studies, Vol.12, No.2, pp.135-164

Beattie, Alan (2009) “A gap to fill”, Financial Times, $2^{\text {nd }}$ March, pp.10: London

Bhagwati, Jagdish (1966) The Economics of Underdeveloped Countries, London: World University Library.

Boothe, J. (2008) “Underlying Strength of Emerging Economies", Financial Times, 5 November: London

Bradsher, Keith (2009a) "Downturn in Factories Sows Fear Across Asia”, International Herald Tribune, $22^{\text {nd }}$ January: Paris.

Bradsher, Keith (2009b) “In Downturn, China Sees Path to Growth”, The New York Times, $17^{\text {th }}$ March: New York 
Bush, Ray (2007) Poverty and Neo-liberalism, London: Pluto Press.

Chandrasekhar, C.P. and Ghosh, J. (2004) The Market that Failed: a decade of neoliberal economic reforms in India, New Delhi: Leftwood books.

China and India: Opportunities and Challenges for UK Business (2009) BERR Economic Paper 5, February, London: Department of Business Enterprise \& Regulatory Reform. (http://www.berr.gov.uk)

Damodaran, V. (2007) “Famines in Bengal”, The Medieval History Journal, vol. 10, issues 1-2, pp.143-181, London: Sage Publishers.

Dasgupta, S. and Singh, Ajit (2006) "Manufacturing, Service and Premature De-industrialization in Developing Countries”, Centre for Business Research, University of Cambridge working paper. (www.cbr.cam.ac.uk/pdf/WP327.dpf)

Davies, M. (2001) Late Victorian Holocaust, Elnino Famines and Making of the Third World, London

Dirks, N. (2006) The Scandal of Empire, Cambridge Massachusetts: Harvard University Press.

Dunning, J.H. (2001) “Globalization and FDI in Asian Developing Countries”, in R. Thrope and S. Little (eds.) Global Change - the impact of Asia in $21^{\text {st }}$ century, London: Palgrave

Dyer, Geoff (2009a) “China becomes the third largest economy”, Financial Times, 15 January, pp. 5, London.

Dyer, Geoff (2009b) “China’s Dollar Dilemma”, Financial Times, $23^{\text {rd }}$ February, London

Fallows, James (2009) “China’s Way Forward”, Atlantic Monthly, April

Felton, A. and Reinhart, C. (ed.) (2008) The First Global Financial Crisis of the $21^{\text {st }}$ Century (www.voxeu.org/index.php?=node/1352)

Fischer, Stanley (1997), “Capital Account Liberalization and the Role of IMF”, Speech at the IMF Annual Meeting, 19 ${ }^{\text {th }}$ Sept..http://www.imf.org/external/np/speeches/1997/091997.htm.

Fischer, Stanley (2003) “Globalization and its Challenges”, American Economic Review, May, Vol. 93, No. 2, pp.1-30

Girdner, Eddie J. and Siddiqui, Kalim (2008) "Neoliberal Globalization, Poverty Creation and Environmental Degradation in Developing Countries", International Journal of Environment and Development (IJED), January-June, Vol.5, No.1, pp. 1-27

Greenough, P.R. (1982) Prosperity and Misery in Modern Bengal - the famines of 1943-44, Oxford University Press: New York.

Glyn, Andrew (2006) Capitalism Unleashed: Finance, Globalization and Welfare, London: Oxford University Press.

Goldman Sachs (2003) “Dreaming with the BRICs: The Path to 2050”, Goldman Sachs Global Economics Paper, No: 99

Goldman Sachs (2007) "BRICs and Beyond”

Goldman Sachs (2008) "The Expanding Middle: the Exploding World Middle Class and Falling Global Inequality”, Goldman Sachs Global Economics Paper, No: 170 
Government of India (2007) Indian Ministry of Statistics and Program Implementation, Statistical Abstract India, New Delhi: Government of India.

Government of India (2008) Central Statistical Organization (CSO), National Accounts Statistics, accessed on $25^{\text {th }}$ March 2008: New Delhi. (http://www.mospi.gov.in/mospi_cso_rept_pubn.htm)

Habib, Irfan (1975) “Colonization of the Indian Economy - 1757-1900”, Social Scientist, Vol. 3, Issue 32, pp. 23-53

Harvey, David (2006) The Limits to Capital, London: Verso Hunter, W.W. (1872) Annals of Rural Bengal, London: Smith, Elder \& Co.

International Monetary Fund (2007) World Economic Outlook, April, Washington DC: IMF International Monetary Fund (2008) World Economic Outlook, October, Washington DC: IMF

International Monetary Fund (2009) Staff estimates for 2009, January, Washington DC: IMF Jacobs, S. and Calland, R. (eds.) (2002) Thabo Mbeki’s World, London: Zed Books.

Jacques, M. (2009) "Global recovery rests on a fresh US approach to China”, The Guardian, $13^{\text {th }}$ Feb. http://www.guardian.co.uk/commentisfree/2009/feb/13/china-economics

Keynes, J. M. (1949) The General Theory of Employment, Interest and Money, London: Macmillan.

Kotz, David (2008) “Contradictions of Economic Growth in the Neoliberal Era”, Review of Radical Political Economy, Vol. 40, No. 2.

Krugman, Paul (2009) “Fighting off Depression”, Internal Herald Tribune, $6^{\text {th }}$ January: Paris. Kumar, D. and Desai, M. (eds.) (1983) The Cambridge Economic History of India, Vol. 2, London: Cambridge University Press.

List, Friedrich (1983) The natural system of political economy, 1837, translated by William Otto Henderson, London: F. Cass.

Macalpin, M. (1983) Subject to Famine: Food Crisis and Economic Change in Western India, 1860-1920, Princeton

Maddison, Angus (1998) Chinese Economic Performance in the Long Run, Development Centre, Paris: OECD.

Maddison, Angus (2007) Historical Statistics for the World Economy, Development Centre, Paris: OECD.

Marx, Karl (1961) Capital, volume one, Moscow: PPH Publishers

Munchau, W. (2009) “Global Policy Shortcomings Will Cost Us Dear”, Financial Times, $2^{\text {nd }}$ March: London

Nocera, J. (2008) “How India Avoided a Crisis”, New York Times, 20 ${ }^{\text {th }}$ December

Patnaik, Prabhat (2000) The Performance of the Indian Economy in 1990s, South Asia, Vol. xxiii (Special Issue) pp.193-205

Patnaik, Prabhat (2009) “The Economic Crisis and Contemporary Capitalism”, Economic and Political Weekly, Vol. XLIV No.13, pp. 47-54 
Polanyi, Karl (1944) The Great Transformation: The Political and Economic Origins of Our Time. Boston: Beacon Press

Robinson, Joan (1965) “Kalecki and Keynes”, in Collected Economic Papers, Vol. 3 London: Blackwell.

Rodrik, D. (2006) “What's so Special About China's Exports?” China and the World Economy, Vol. 14:5, pp. 1-19.

Sachs, Jeffrey (2003) "Dreaming with the BRICS", quoted in China and India: Opportunities and Challenges for UK Business, 2009. BERR Economic Paper 5, February, London: Department of Business Enterprise \& Regulatory Reform, pp 6

Sachs, Jeffrey (2009) "What the World needs now" The Guardian, $22^{\text {nd }}$ February (accessed on 24th February 2009)

http://www.guardian.co.uk/commentisfree/2009/feb/20/globalrecession-economics/print

Schott, P. (2008) “The Relative Sophistication of Chinese Exports”, Economic Policy, pp 5-49

Sen, Amartya (1981) Poverty and Famines: An Essay in Entitlements and Deprivation, London: Oxford Publishers.

Siddiqui, Kalim (1990a) "Political Economy of Terrorism - The Process of Capital Accumulation and the Problems of Democratic Rights in Latin America”, in V.D. Chopra (Edi.) Genesis of Indo-Pakistan Conflict on Kashmir, (pp 212-225) New Delhi: Patriot Publishers.

Siddiqui, Kalim (1990b) "Historical Roots of Mass Poverty in India” in C.A. Thayer et al. (Eds.) Trends and Strains, (pp 59-76), New Delhi: Publishing House.

Siddiqui, Kalim (1996) "Growth of Modern Industries under Colonial Regime: Industrial Development in British India between 1900 and 1946”, Pakistan Journal of History and Culture, January, Vol. xvii/1, pp 11-59.

Siddiqui, Kalim (1998) “The Export of Agricultural Commodities, Poverty and Ecological Crisis: A Case Study of Central American Countries”, Economic and Political Weekly, Sept. 26, 1998, No. 39, vol. xxxiii, pp. A128-A137

Siddiqui, Kalim (2008a) “India's Obsession with Economic Growth” (in Norwegian), Klassekampen, 26th August, (pp 8-9), Oslo, Norway

Siddiqui, Kalim (2008b) “Recent Global Financial Crisis” (in Norwegian), Klassekampen, 20th October (pp. 16), Oslo, Norway

Siddiqui, Kalim (2008c) "Globalization and Developing Countries: Opportunities or Marginalization?”, pp.46-71, in Verma, S. B. et al, eds., Globalization at the Cross Roads, New Delhi: Sarup \& Sons Publishers.

Siddiqui, Kalim (2009a) “Globalization and Neo-liberal Economic Reforms in India: A Critical Review” in Ganguly, R. et al (Eds.) Globalization and its Impact on Indian Society, New Delhi: Prentice Hall.

Siddiqui, Kalim (2009b) “The Political Economy of Growth in China and India”, Journal of Asian Public Policy (JAPP), March Vol.1, No.2, pp.17-35 
Simmons, Colin (1985) "De-industrialization, Industrialization and the Indian Economy, c.1850 - 1947”, Modern Asian Studies, Vol.19, issue 3, pp.593-622

Soros, George (2009) “The Game Changer”, Financial Times, $28^{\text {th }}$ January.

Stiglitz, Joseph (1997) “How to fix the Asian economies”, New York Times, $31^{\text {st }}$ October

The Economist, (2008a) “The Decoupling Debate”, 6 th March, London: The Economist

The Economist, (2008b) "When Fortune Frowned - A special report on the world economy”, $11^{\text {th }}$ October, pp. 33-36, London: The Economist

The Economist, (2008c) “Capitalism at Bay”, 18 ${ }^{\text {th }}$ October, pp. 13-14, London: The Economist.

The Economist, (2009a) "World Economy - Accelerating downhill”, 17 $7^{\text {th }}$ January, pp.13-14, London: The Economist.

The Economist, (2009b) “Asia’s sinking economies - Asia’s suffering”, 31 ${ }^{\text {st }}$ January, pp.10, London: The Economist.

The Economist, (2009c) "South Africa's Economy - Tough times ahead”, 14 $4^{\text {th }}$ February, pp.62-63: London

The New York Times (1998) $7^{\text {th }}$ January, New York

Wade, Robert (1998) “The Asian Debt and Development Crisis of 1997”, World Development, Vol.26, No.8, pp.1535-1553

Wade, Robert (2009) “Steering Out of the Crisis”, Economic and Political Weekly, $28^{\text {th }}$ March, Vol. XLIV, No.13, pp.39-46

Williamson, J. (1994) The Political Economy of Policy Reform: a view from Latin America, Washington D.C.: Institute of International Economics.

Winters, L. and Yusef, S. (2007) Dancing with Giants: China, India and the Global Economy, Washington D.C: The World Bank.

Wolf, Martin (2008) “China Changes the whole World”, Financial Times, $23^{\text {rd }}$ January, pp.2: London.

World Bank (2008) World Development Indicators (CD-ROM), Washington D.C.: World Bank.

\section{Notes}

1. Angus Maddison (2007) Historical Statistics for the World Economy, Development Centre, Paris: OECD

2. For a lucid exposition of the decoupling theory, reference may be made to The Economist, $6^{\text {th }}$ March 2008, while for an analysis see Chandrasekhar and Ghosh (Business Line, $10^{\text {th }}$ February 2009).

3. For more detail discussion on this issue see Kalim Siddiqui (2009a \& b)

4. Note that investment and export constitute major sources of demand for industrial goods.

5. For example, India's merchandise export declined from $24.3 \%$ to $2.2 \%$ between $2006-07$ and 2007-08, however the fall in growth of services exports was much sharper, from $34.5 \%$ 
to minus 4.9 \% during the same period (see Indian Ministry of Statistics and Programme Implementation, 2007, Statistical Abstract India).

6. The much faster growth of India's exports is attested to by the fact that between 1995and 2000 India's share in world merchandise exports went up from $0.58 \%$ to $1.0 \%$; the increase in the share of services exports during the same period was much larger from $0.58 \%$ to $2.7 \%$, (IMF 2007)

7. IMF growth figures pertain to the end-year, whereas Indian government growth estimates are for end-March.

8. Take for example Andrew Carnegie built giant steel company in the United States by feeding off the state sector - building naval vessels during the World War. The rapid economic growth witnessed during the $2^{\text {nd }}$ World War in the US, when the country basically followed the command economic policies.

9. Until the $2^{\text {nd }}$ World War, the US was the most protectionist country in the world. At present, the US government spends a large amount of money in defense industry. In proportional terms, the country spends much more than European countries or Japan in supporting research and development and thereby steering them into certain directions. For more detail on the question of free trade see Girdner and Siddiqui (2008:1-27)

10. "Four Asian currencies plunge to record lows... In the first six day of the 1998 the Indonesian rupiah lost $26 \%$ of its value, after a $56 \%$ decline in 1997 made it the world's worst-performing currency (New York Times, $7^{\text {th }}$ January 1998 D2).

11. In 1997 the fast growing East Asian countries saw their economies overwhelmed by financial crisis. These countries then witnessed investor panic and capital feeling their region. Their currencies plummeted in values and their biggest companies wrestled with bankruptcy. Then IMF insisted that these countries should repay their debts by increasing their exports. As the value of their currencies plunged against US dollars the result was good exported from these regions became very cheap for the consumers in the West (see Wade 1998; Stiglitz 1997). 